\title{
Conflict, Dialogue and Justice: Exploring Global Citizenship Education as a Generative Social Justice Project
}

\author{
Lynette Shultz \\ University of Alberta \\ 1shultz@ualberta.ca
}

\begin{abstract}
If we are to live in this extensively interconnected world we need to find ways to understand the edges of democracy - those places where people and lives are moved to the margins and silenced - and to provide new ways to enact citizenship in its multiple locations with and beyond nation states. Drawing on theoretical understandings of deliberative democracy as a challenge to conventional models of liberal democracy, and the praxis of conflict transformation, this article frames processes of social justice as a platform for citizenship education. It examines the way that addressing conflict involves understanding the complexity of social change within a globalized and globalizing world. The conclusions provide conceptualizations for co-creating educational processes of engagement that work to provide expansive inclusion.
\end{abstract}

\section{Introduction}

This article examines the potential that education holds in helping to negotiate the deep differences and subsequent conflicts that are surfaced in a "globalized and globalizing world", a description I use to capture the current system of international, intercultural, and interpersonal relations and structures that exist as a result of both ideologically and technologically enhanced global connections. While global structures and, to some degree, relationships have been given excellent description through studies of the political economy, I am interested, in this study, in the dynamic processes that exist within this system and their generative possibilities. To achieve this, I explore the question: can conflict serve to (re)engage us as political subjects with an intention of generating social justice through new relationships within and across borders, but also with the structures that constrain and enable these relations? Always lurking behind such a question is the consideration of whether such engagements are possible without succumbing to neoliberalism's demand for an apolitical, obedient, economic (worker) citizen. The examination of these questions suggests the need for a more robust citizenship education that is more just in practice and impact. While finding entry points for challenging the hegemony of global structures can be difficult as they sit not only on economic structures, but also social and cultural institutions, it is at these critical points that the dynamics of change and the work of justice can be most clearly seen. It takes tremendous structural effort to keep justice from emerging: immense military budgets fund projects to control dissent and discipline dissenters; lobby groups Journal of Contemporary Issues in Education, 2009, 4(2), pp.3-15 ISSN 1718-4770 @ 2009 University of Alberta http://ojs.educ.ualberta.ca/index.php/jcie/ 
of and for the global elite work relentlessly to control global, regional, and national policies; intense discursive closure diminishes spaces for public citizenship access and action. These efforts can seem so all encompassing that they pose the risk, as Smith (2009) suggests that a global system enters into the realm beyond critical debate. But, if we look carefully, we will see that there are structural cracks and relations of resistance where justice might emerge. It is, therefore, imperative that this justice be hosted into a public sphere, a commons, where contested and seemingly unfamiliar voices and experiences can be heard.

Arandathi Roy (2009) explores the limits of current manifestations of liberal democracy in her book "Listening to Grasshopper: Field notes on Democracy" and she concludes that "fascism itself can only be turned away if all those who are outraged by it show a commitment to social justice that equals the intensity of their indignation" (p. 21). It is not enough to critique but we need also to engage in the public sphere in ways that are more just. These ways need to be learned into being and such educational processes will require a foundation in re-imagined democratic spaces. If we are to live in this extensively interconnected world we need to find ways to understand the edges of democracy- those places where people and lives are moved to the margins and silenced- and provide new ways to enact citizenship in its multiple locations within and beyond nation states. This is particularly challenging in contemporary neoliberalized contexts where technology and an empowered global elite have enhanced globalization into globalism, a belief system which supports the creation of a global culture based on economic liberalism, where the norms and values of this dominant group erase, without regret, whole social groups, epistemologies, and non-economic ways of being within the social and natural world (see for example Abdi, 2009; Odora Hoppers, 2000; 2009; Weber-Pillwax, Kelly, Shultz \& Lange, 2009). A problematic expectation and normalization of consensus has risen from this context that aids in the erasing process. Consensus, when cloaked in the demands of postmodern neoliberalism, suggests that progress, or wellbeing, or even personal success, is contingent on everyone agreeing to find ways to make things (the current system) work. Such consensus comes at the expense of any or all who might not be willing or able to agree. This ultimate shortsightedness has brought increased inequality and dire circumstances for more and more of the world's people. But there may be some rays of light in this fog of globalism.

While we seek to understand the puzzles of a political elite who become both complacent and self-serving (see Rancière, 2006) we also see the global elite are getting worried. Environmental issues and the immediacy of climate change are having a direct impact on the lives of the elite (albeit minimal compared to the impacts on those living in poverty). In addition, there is the 2008-09 economic recession, where the cracks in the super-capitalist system of economic liberalization have been revealed at the same time that economic power is shifting to a more broad global elite as demonstrated by the global governance shift from the G8 to the G20 with little resistance from the once all powerful " 8 ". African governments and citizens are increasingly being heard and their demands for control of resources and knowledge are creating 
waves throughout all sectors. It is currently in the self-interest of the elites to begin to talk of social justice and it seems that talk has begun given the increase in theoretical and practical literature being published. However, my concern is that much of this literature is an "enclave approach" to social justice, a product of an elite who create their own enclosure to deliberate about justice. The result is a declaration of great urgency for change but little for difference. Social justice within the elite bubble - this change with no difference- where likeminded privileged people identify the issues and paths of change, can only lead to increased conflict that escalates because the very processes that might lead to the transformation of conflict have been limited by the exclusivity of the participants. Many educational efforts are also couched in the language of social justice that sits tidily outside spaces where change can be either learned or practiced. This serves to keep people on the periphery, and their search for justice marginalized and certainly ineffective.

\section{On the Edges of Democracy: Conflict and Seeking the Path of Justice}

Processes of erasure, including focusing on consensus and silencing dissent, move difference away from the centre, into the borders of social and political relations. Such processes are framed and legitimized by suggestions that conflict is the ending of relationships and consensus the savior. However, the word conflict, from the Latin conflictus, with its prefix "con" meaning "together in combination or unity" (The Concise Oxford Dictionary of English Etymology, 1996) itself suggests a strong relationship that includes both something in common as well as difference. The practical experiences and work of Adam Kahane (2007/2008) inform understandings of how conflict in its fullness might be addressed through deliberation and dialogue that includes conceptualizations and engagement of love and power. He demonstrates through his work with groups with longstanding histories of conflict that the combined need for unity, expressed as love (see Tillich, 1954) at the same time as the drive to exert oneself into the social world through the use of power is the foundation of not only justice but in fact, the continuation of any social relations. As Martin Luther King Jr. declared in a speech shortly before his assassination,

What we need to realize is that power without love is reckless and abusive, and love without power is sentimental and anemic. It is precisely this collision of immoral power with powerless morality, which constitutes the major crisis of our times. (Martin Luther King, Jr., 1967)

Kahane's use of love and power to find ways of group decision-making through co-creating new processes of engagement, works to provide expansive inclusion that allows for authentically generative ideas and actions to be identified, critiqued, and applied. These processes, while moving engagements into the much more complex and open-ended area of conflict transformation, create deliberative space where difference can be named and included, thereby providing much more moral and political legitimacy for active citizenship engagement than 
consensus models where it is assumed that citizens will agree (or should agree) with the views and interests of the dominant group. Lederach (2004) who also draws his theoretical frameworks from engagement with communities in conflict, describes a similar relationality as the foundation necessary for justpeace, "an orientation toward conflict transformation characterized by approaches that reduce violence and destructive cycles of social interaction and at the same time, increases justice" (p. 182). Justpeace requires a public sphere where love and power are engaged, and citizens respond individually and collectively through both cooperation and assertiveness as a usual practice. Extremism and violence erupt from the closure of the public commons and the refusal to engage in the differences and diversity of the people who are impacted by the decisions and actions that are located within that space.

This deliberative turn toward conflict frames both understandings and practices of democracy. As Guttmann and Thompson (1996; 2004) argue, such democracy depends on the deliberation that citizens engage in to express their positions, interests and preferences. While it might be a desire for conflict transformation and a drive for unity, or love as Kahane describes it, that brings people to deliberate, the dynamics of power are visible in positioning and representation within these contexts. Deliberative democracy depends on disagreements (rather than agreements) that are not only of moral consideration but also based on structural and procedural aspects. Dryzek (2005) proposes that deliberation requires

three tests [be applied ] to secure the intersubjective understanding prized by deliberative democrats. Once we move beyond ritualistic openings, communication is required to be first, capable of inducing reflection; second, noncoercive; and third, capable of linking the particular experience of an individual or group with some more general point or principle. (p. 224)

Social justice, as such a principle, provides a vital platform for both democracy and citizenship. The conceptualization of social justice here draws on work over the past several years that established justice to include the distribution of benefits and burdens of society (Rawls, 1971; 2001) but also considerations of how issues of recognition impact such distribution (Fraser, 1997; 2009; Young, 2000). Engagement is also a key factor in addressing issues of distribution and recognition in that participation as a political and social subject are required to have access to public spaces where decisions about distribution are made. As Fraser (2009) identifies, in a globalized and globalizing world, distribution (or redistribution), recognition and participation have added complexities in that justice issues are increasingly complex where they can be seen

traversing multiple discourse arenas, some formal and some informal, some mainstream and some subaltern, the locus of argument shifts with dizzying speed. And far from going without saying, the topography of debate is itself an object of dispute. Offshore contestants strive to pierce the bounds of domestic debates, 
even as nationalists and country-level democrats seek to territorialize them. Meanwhile states and corporations work to contain disputes within regional juridical institutions, even as transnational social movements strain to widen them. Thus, the very shape of controversy, uncontested in normal discourse, is here a focus of explicit struggle. Even as they dispute substantive issues, then, the contestants also rehearse deep disagreements about who is entitled to address claims to whom concerning what; about where and how such claims should be vetted; and about who is obliged to redress them, if and when they are vindicated. (p. 52-53)

This suggests the need for a strengthened public sphere within a globalized context. Global citizenship is a frame that expands the inclusiveness of citizenship by legitimizing political and public spaces that extend beyond the dominant actors (in terms of power and knowledge) and provides opportunities for the knowledge and engagements of many who have been denied citizenship rights and engagements in the system as it currently exists. Justice requires that in order for there to be a fair and positive outcome for all, there needs to be publicness in procedure and publicness in substance. As Hampshire (2000) argues, justice requires processes that are both absolute and negotiated. Procedural justice, based on the principle of "hear the other side" must be absolute. We cannot achieve justice without creating public space for the multiplicity of voices and experiences of justice and injustice, and this public space must be guaranteed without discrimination or exclusion. On the other hand, substantive justice is always contested and must be polyversal and negotiated. Attempts to suppress the disputes that emerge from such negotiations, for example, through consensus models of decision-making, is domination. The need to focus on equity as well as equality is key here. Since substantive justice is always disputed and open to attempts of domination, justice requires that there be processes in place to address its inherent conflicts. This suggests that, in tension with current neoliberalized concepts of the harmonious/harmonized and de-politicized public, a just public sphere requires a reimagining of the political subject and citizenizing processes to handle justice as conflict.

\section{Dynamics of Social Change: Path of Justice versus Path to Justice}

Drawing on the conflict transformation work of Lederach (2004) and Kahane (2004/2007) this section will work to frame processes of social justice to provide a platform for citizenship education. Kahane suggests that addressing conflict involves understanding the complexity of social change. Given that social conflicts are embedded within a context, it is important to understand issues and processes of justice as part of complex systems. This complexity includes dynamic complexity "which means that cause and effect are far apart in space and time, and so are hard to grasp from firsthand experience" (p. 1); social complexity recognizes the pluralism in worldviews, knowledges, and experiences that are held by the people involved in any justice issue or social problem; and generative complexity which addresses the 
way in which events "unfold in unfamiliar and unpredictable ways" (p. 2). While many concepts of justice suggest that justice is an endpoint requiring the uncovering or identification of a path to justice, this understanding of justice suggests that engaging in the processes of justice requires us to take a path of justice where change is understood as disruptive and unpredictable. Scharmer (2007) describes this as emerging complexity where "solutions to problems are unknown; the problem statement itself is unfolding; and who the key stakeholders are not always clear" (p.63). The greater the dynamic complexity, the more significantly social complexity will play an intervening role in the conflict. With a problem that is of low dynamic complexity, for example, where a school in a neighborhood is closed as a budget balancing strategy, the policy and the impact are quite easily linked and can be addressed within a localized context. However, if the problem is the lack of participation of racialized groups in higher education, the cause and effect are much farther apart and therefore, the social complexity of the situation requires a systemic approach to understanding the issue, the conflicts inherent in the issue, and any actions that might be taken to address the issue. Scharmer suggests that such an issue will demonstrate emergent complexity as people begin to sort through the embeddedness of the problem. If there is an interest in actually changing how and by whom things are done, then there is a need (individually and collectively) to commit to working within this complexity. It is the location where it is possible to actually generate ideas that reframe issues and make it possible to act in different ways. This emergence and embeddedness suggest the need to learn creative ways of engaging in both the social and dynamic aspects of the conflict. Kahane (2004/2007) describes such co-creation of new realities in his work with conflict that is founded on finding new ways to talk and listen across and between differences.

Lederach (2004) also addresses social complexity as a necessary part of transforming situations of conflict. His conceptualization suggests that addressing both vertical capacity and horizontal capacity will provide the context that will allow social change. Horizontal capacity is "the ability to build and sustain relational spaces of constructive interaction across the lines of division in systems and societies divided by historic patterns of identity conflicts" (p. 182). Not to be mistaken with economic development models that focus on capacity as an individual enhancement without consideration of social or political contexts, horizontal capacity within social conflict transformation highlights the need for engagement between and among social groups. In addition, Lederach (2004) describes vertical capacity as processes of relationship building across levels of leadership, authority and responsibility within a society or system, from grassroots to highest, most visible leaders (p. 183). This awareness suggests that each level has different needs and unique contributions to make but ultimately they are interdependent and require explicit fostering of constructive interaction across levels. The overall integration of horizontal and vertical capacities of a society indicate "strategies for seeking change within a divided system or society that explicitly engenders and supports processes that link individuals, networks, organizations, and social spaces" (p. 183). 
If we bring this together with Dryzek's (2005) idea that links identities with discourses and the need for locating deliberation between competing identities and discourses within the public sphere, instead of privatized conflict between individuals or individuals and the state, we see how horizontal capacity and social complexity can help locate the processes that are needed to enact procedural and substantive justice. While so often we strive to close down conflict by attempting simplistic ways to decrease the complexity of a situation at the time when what is really needed is an open model of creative and full engagement. The greater the complexity of the issue and context, the more creative our responses need to be if we are to tap into the generative potential of conflict and the people who are part of it. In this there is a powerful role for education that is socially and politically creative suggesting an important place for citizenship education that adds to the public sphere.

\section{Does Education Have a Role in Creating a More Just World?}

While some who agree with the discourses of the knowledge economy and education as a tool for individual capacity building might argue that the issues of globalization, difference, and justice are outside the work of educators or the field of education, there is a long history of educationists committed to transforming injustice and creating the possibility that justice, in its broadest manifestations, might be the norm rather than the exception (see for example Abdi, 2008; Abdi \& Shultz, 2008; Apple, 1999; Dewey, 1916; Giroux, 1994; Greene, 1988; Freire, 1970; McLaren, 2006; 1994; Nyerere, 1967; 1973). However, these works also describe the conflicting demands of education for citizenship that reflect the conflicting demands of democracy in a global capitalist system (see also Smith, 2009). One example where this is demonstrated is in the experiences of children who are exploited through the practices of contemporary slavery and other forms of exploitive work (see Shultz, 2008). Millions of children form an invisible work force that supports the relentless search for "production efficiencies" by global corporations and the possibility that workers can be paid nothing. Such ideas drive concepts of "efficiencies" to such obscene levels that child slavery has become a problem in every country in the world. These practices are illegal according to multiple international agreements, as well as national and local laws. The Convention on the Rights of the Child supports children's rights to protection, provision and participation. However, in the logics of neoliberalism, it is the individual (rather than the state) who should be responsible for provision and protection through participation in the economic system. These logics are used by policy makers, employers, and even educators, to state that children like to participate, so why not let them participate in the ultimate citizenship experience: work? The discourses within global organizations has reached a most cynical place where we hear cries that [poor] "children have a right to work" beside equally loud calls that [non-poor] "children have a right to education". This one example, among a myriad of places where individuals and particular groups continue to face oppressive exclusions, exposes the contradictions of liberalism and the challenges of limits places on how and who might contest and shape decisions within current globalized notions and 
practices of democracy. These contradictions highlight the very urgent need for critical social justice education as citizenship education.

History has demonstrated that educators become the foot soldiers of oppressive policy and regimes when they become compliant and disengaged (or perhaps distracted) through excessive accountability agendas, top-down reform discourses, and efficiency demands (see above authors), resulting in schools becoming places where society is learned rather than created. Social justice, however, demands that we ask: are we educating obedient citizens or engaged and deliberative citizens able to participate fully in creating a strong public sphere? As political subjects, citizens have roles in shaping not only their immediate circumstances but participating in the wider encounters with vastly diverse and contested discourses that shape the political, social, and economic structures and processes from the local to the global. Schools and other community education sites can be arenas where such encounters are experienced and where citizenship, as a practice, becomes the norm. This will require that educators resist attempts to homogenize and erase difference as they look for ways to secure a mass identity, through for example, the student as consumer, or through a narrowed view of popular culture. Teachers often welcome the diversity that arrives at the school but abhor diversity within the school itself. The diverse backgrounds, knowledge, and experiences of children might be welcome as a starting point for schooling but these children will certainly be expected to quickly erase this diversity (except in very superficial ways that we see in, for example, cultural celebrations involving differences in food, music, and dress) and to engage in non-diverse activities and to achieve the exact outcomes as all other children by the end of their schooling. Even more destructive can be the schooling experiences where consensus is achieved through the erasure of students themselves as they attempt to exert their experiences into the social realm. This consensus perpetuates the understanding that conflict is a private/privatized issue and is not to be part of the public sphere. This requires a consistent practice of silencing and excluding which is particularly harmful to those who need most to exert their citizenship rights into public space. The homogenized minds of youth create the bordered enclaves that ensure change will not lead to transformation. Is it any wonder that processes of passive consensus are so easily presented as the norm of democracies?

\section{Education and Social Justice: A Global Citizenship Approach}

What kind of education will take us from the passive citizen to the engaged citizen, able to participate in co-creating social justice? If we take as a starting point that love and power work in ways that, as Kahane (2004/2007) suggests, to compel people to engage in social relations, then we have a justification for identifying ways that this engagement might take place. This also implies a much-contested social space that requires understanding the embeddedness of conflict and justice at the same time as we resist the limitations of justice models premised on linear and exclusive processes. It is important to note here that those who make up the elite might read this 
and suggest that life is much better if conflict is avoided. Surely this is a sign that, in fact, one is in a privileged place where there seems a choice whether one needs to see injustice or not. But as I argued earlier, in the current globalized world, the elites are having a harder time maintaining this privileged blindness.

\section{Education and Deliberative Democracy}

As Gutmann and Thompson (1996; 2004) highlight, deliberative democracy is a second order theory in that it resists claims that eliminate other perspectives and seeks to provide a way of dealing with conflicting theories of democracy. This is in contrast to attempts to present first order theories that are premised on the idea that one theory must prevail, through the elimination of alternatives. The arguments in this paper suggest that citizenship education shares a foundation as a second order theory. It is through citizenship education that we come to understand the competing claims and perspectives that create both justice and injustice. Understanding education as processes of social justice or path of justice is a key contribution to creating a public sphere where the conflict that is inherent in justice can be surfaced, engaged and possibly reframed. This suggests that citizenship education must address the need for citizens able to engage in political deliberations with the intent to not only contest and influence the public sphere but contribute to co-creating alternatives to expand and enrich this sphere. The challenge in a globalized world is how to educate for participation in a global public sphere.

\section{Global Citizenship Education and the Embeddedness of Social Justice}

Education, or specifically public education, acts to create the public sphere and is both place and process where the issues of society are surfaced. It is through citizenship education that access to the public sphere and to processes of procedural and substantive justice are made available to those beyond the empowered elite. Effective citizenship education provides the space and capability for people to engage the dissensus of the public sphere as political subjects. This is not an abstract space but one where disputed knowledges and ways of living are recognized as vital contributions to the wellbeing of the whole of humanity. The very real consequences of the continued exclusion of these knowledges and experiences can be seen in the diminished life conditions and possibilities of the world's indigenous people, of those who have been excluded in the global economic order and who are members of the billions of people who live in poverty, and of those who through living outside dominant standards of masculinity, affluence, and racial profile are subjected to ongoing and profound marginalization. The concept of global citizenship can be helpful in embracing the totality of this complexity if we see the "global" as the vast human diversity that exists. When one shifts their understanding to a systemic and inclusive engagement with those who are kept on the margins, there is a tremendous urgency added to the project of social justice. Global citizenship education as a container for the dynamic and social complexity of embedded social justice helps make sense of the complexity at the local level as well. If the dynamic complexities of social justice issues are 
understood as globally distant in cause and effect (i.e. through global policy, global economic decision, and interactions as suggested by Fraser, 2009), then the local citizens understand the need to engage the wider social complexity and work to engage the emergent complexity in cocreative ways.

\section{Dialogic Space for Citizenship Education}

As Lederach (2004) helps us understand, the need for peace education to add to the public good is captured in the idea of justpeace, where peace is linked to the project of justice. While consensus and conflict resolution models used in peace education can lead to the very issues that perpetuate injustice- that of erasure and silencing dissent- the importance of engaging in creative conflict transformation processes addresses conflict as a normal part of justice. The need to create a generative educational space where co-created solutions to complex problems are learned into being is quite clear. Such dialogic citizenship education spaces might bring the complexity of embedded social justice issues together with the creative potential of emergent processes to create the necessary conditions for social justice to emerge into a renewed public sphere. As we witness countless examples of citizenship space being closed in the current intensively neoliberalized political spaces, it is clear that what is needed is a renewed political subject who is capable of engaging in this very creative public arena. For example, current Canadian academics are facing sanctions for engaging with the Israel - Palestine disputes (see www.caut.ca); civil society members are forced to limit their public education activities due to intense funding restrictions on organizations who might be taking an advocacy role in society (see www.ccic.ca); and governments have large communication management departments to contain and reframe political messages and information about governments actions; journalists find former political media scrums limited to predetermined question and answers that provide photo opportunities rather than engagement in the public business of the country (see Centre for Constitutional Studies http://www.law.ualberta.ca/centres/ccs/ ). These acts all create the context for de-citizenization. Passive political subjects (May, 2008; Rancière, 2006) are created in contexts where individualism and individual capacity trump social concern and action, and where government institutions are expected to protect this individualism even at the expense of creating a strong public sphere. May (2008) suggests Rancière's framework for active equality is a framework for the today's citizen who finds him/herself "politically dispossessed" (p. 142). The kind of deliberative democratic space that is required in which to host the emancipated citizen, as Dyrzek (2006) describes, is deliberative where "participants are amenable to changing their minds as a result of reflection induced by non-coercive communication" (p. 27) and deliberative when the space "provides opportunities for participation by all those affected by a decision" (p. 27). Such dialogic deliberative locations can be the container for the emergent processes of justice as the possibility of creative engagement with the diverse people, ideas, and experiences are included as part of an inclusive public sphere. 


\section{Conclusions}

This article has argued for a reconceptualization of citizenship education based on an understanding of deliberative democracy in a globalized and globalizing system of structures and human relations. This global citizenship education can be a project of social justice if consideration is given to the embeddedness of conflict and justice within all aspects of the public sphere and if this renewed sphere is cast as a generative citizenship commons. Education is a key to learning the citizenship and justpeace needed to ensure full and inclusive global citizenship into being. If education is to achieve its transformational potential it will not be education about citizenship and not education for citizenship, but education as citizenship that includes an understanding of the global aspects of our political subjectivities. We are educated to be citizens through our citizenship, which is based on being active political subjects. It is time to do things differently. The urgency is real as we can understand by listening to those who live most closely to the realities of marginalization and a diminished public agency, whether from an oppressive economic system, through the legacies of racism and colonialism, or through a location on the planet where the impacts of climate change present catastrophic daily challenges. It can be time when change is hosted in ways that will actually make a difference to each and all of these challenges that we share as humans on a finite planet and to the social justice that must exist as a foundation of human relations. Such change will only come about if we learn new ways to engage in the conflict that is inherent in finding and creating justice whether at the local or global level. A recent sign at a street demonstration stated, "War is so yesterday". Indeed it is time that we recognized that humans have the capacity to generate much more creative solutions to conflict. This paper has argued for the important role that educators can play in educating citizens with this capacity. 


\section{References}

Abdi, A. A. (2008). De-subjecting subject populations. In A. A. Abdi \& L, Shultz (Eds.), Educating for Human Rights and Global Citizenship. (). New York: SUNY Press.

Abdi, A. A. (2009). Recentering the philosophy of the foundations of knowledge: The case of Africa with a special focus on the global role of teachers. Alberta Journal of Educational Research, 55(3), pp. 269-283.

Abdi, A. A. \& Shultz, L. (Eds.). (2008). Educating for human rights and global citizenship. New York: SUNY Press.

Apple, M. (1999). Power, meaning and identity: Essays on critical educational studies. New York: Peter Lang.

Dewey, J. (1916). Democracy and education. New York: Macmillan Co.

Dryzek, J. (2005). Deliberative global politics. Cambridge, UK: Polity Press.

Fraser, N. (1997). Justic interruptus. Critical reflections on the postsocialist condition. London: Routledge.

Fraser, N. (2009). Scales of justice: Reimagining political space in a globalizing world. New York: Columbia University Press.

Freire, P. (1970). Pedagogy of the oppressed. New York: Seabury Press.

Giroux, H. (1994). Between borders: Pedagogy and the politics of cultural studies. London/ New York: Routledge.

Greene, M. (1988). The dialectic of freedom. New York: Teachers College Press.

Gutmann, A. \& Thompson, D. (1996). Democracy and disagreement. Cambridge, MAS/ London: Belknap Press of Harvard University Press.

Gutman, A. \& Thompson, D. (2004). Why deliberative democracy? Princeton/ Oxford: Princeton University Press.

Hampshire, S. (2000). Justice is conflict. Princeton: Princeton University Press.

Kahane, A. (2004/2007). Solving tough problems: An open way of talking, listening, and creating new realities. San Francisco: Berrett-Koehler Publishers, Inc.

King, M.L. (1967). Where do we go from here: Chaos or community? New York: Harper \& Row.

Lederach, J. (2004). The moral imagination: The art and soul of building peace. Oxford/ New York: Oxford University Press.

May, T. (2008). The political thought of Jacques Rancière: Creating equality. Edinburgh: Edinburgh University Press.

McLaren, P. (1994). Life in schools: An introduction to critical pedagogy in the foundation of education. New York: Longman.

McLaren, P. (2006). Rage + hope: Interviews with Peter McLaren on war, imperialism, and critical pedagogy. New York, NY: Peter Lang Publishing.

Nyerere, J. (1967). Education for self-reliance. Dar es Salaam: Information Services, Govt. of Tanzania.

Nyerere, J. (1973). Freedom and development. London/New York: Oxford University Press.

Odora Hoppers, C. (2002). Indigenous knowledge and the integration of knowledge systems. Glosderry, RSA: New Africa Books.

Odora Hoppers, C. (2009). Education, culture and society in a globalizing world: Implications for comparative and international education. Compare, 39(5), pp, 601 -614.

Rancière, J. (2006). Hatred of democracy. London/ New York: Verso. 
Rawls, J. (2001). Justice as fairness: A restatement (edited by Erin Kelly). Cambridge, MA: Harvard University Press.

Rawls, J. (1971). Theory of justice. Cambridge, MA: Harvard University Press.

Roy, A. (2009). Listening to Grasshopper: Field notes on democracy. Hamilton, CAN: Penguin Publishers.

Scharmer, O. (2007). Theory U: Leading from the future as it emerges. Cambridge, MA: Society for Organizational Learning.

Shultz, L. (2008). Human rights education and contemporary child slavery: Creating child friendly villages when states, communities and families fail to protect. In A. A. Abdi \& L. Shultz (Eds.), Educating for Human Rights and Global Citizenship. (). New York: SUNY Press.

Smith, D. (2009). Critical notice: Engaging Peter McLaren and the New Marxism in education. Interchange, 40(1), pp. 93-117.

Tillich, P. (1954). Love, power, and justice. London/ Oxford/New York: Oxford University Press.

Weber-Pillwax, C., Kelly, J., Shultz, L., \& Lange, E. (2009). Expanding knowledge systems in teacher education. Special issue of Alberta Journal of Educational Research, 55(3), pp.

Young, I. (2000). Inclusion and democracy. Oxford/ New York: Oxford University Press. 